\title{
Helicobacter pylori
}

\section{Mona Z Zaghloul*}

Microbiology Unit, Department of Clinical Pathology, Ain Shams University Hospitals, Cairo, Egypt

Helicobacter pylori infection is one of the most common bacterial infections in the world. It is responsible for most cases of chronic gastritis and peptic ulcer disease, and the main risk factor for gastric cancers (adenocarcinoma and gastric mucosa-associated lymphoid tissue lymphoma). Recent studies suggest an increased $H$. pylori prevalence in patients with various extra gastrointestinal disorders, including skin, cardiovascular, rheumatic, liver diseases $[1,2]$ and respiratory disorders, including chronic obstructive pulmonary disease (COPD), bronchiectasis $[3,4]$ and active pulmonary tuberculosis. The observed associations might be explained by a potential etiopathogenetic role of $H$. pylori infection in these disorders. Estimates suggest that half the world is infected with the bacteria, with an especially high rate of infection in Asia [5]. We know that $H$. pylori causes ulcers, but do all strains of $H$. pylori cause ulcers and why some people experience symptoms while others remain asymptomatic? If we can understand that we may be more efficient at treating and avoiding development of $H$. pylori antibiotic resistance. Helicobacter pylori are a spiralshaped, microaerophilic and Gram-negative bacterium discovered by Marshall and Warren [6]. This bacterium possesses strain-specific virulence factors cytotoxin associated gene $\mathrm{A}(\mathrm{CagA})$ and vacuolating cytotoxin gene $\mathrm{A}(\mathrm{VacA})$ that allow the organism to colonize the gastric mucosa, evade host defense and, finally, damage host tissue $[7,8] . H$. pylori colonization of the gastric mucosa stimulates the release of a variety of proinflammatory cytokines, including interleukin (IL)-1, IL-8 and tumor necrosis factor- $\alpha$. Moreover, a crossmolecular mimicry between bacterial and host antigens exists in $H$. pylori-infected patients. Therefore, $H$. pylori might have a pathogenetic role in diseases characterized by abnormal activation of inflammatory mediators and/ or induction of autoimmunity $[9,10]$. Diagnosis of $H$. pylori infection is based on noninvasive tests, such as serological methods, $14 \mathrm{C}$ urea breath test, and bacterial DNA sequences or bacterial antigen detection in stool by the $H$. pylori stool antigen (HpSA) test [11] which were preferred due to their simplicity and rapidity. In contrast, the direct detection and culturing of $H$. pylori from gastric biopsy specimens requires invasive gastroduodenoscopy [12]. Culture methods require an incubation period of at least 4-7 days. Several factors cause difficulty with culturing of the organism: patchy distributions of the organism on tissues, proper transportation to avoid oxygen and maintain a temperature of $4^{\circ} \mathrm{C}$ [13]. The presence of $H$. pylori or resistance to clarithromycin can be investigated on gastric tissue samples with molecular methods, such as polymerase chain reaction (PCR) and fluorescence in situ hybridization (FISH) [14]. Optimal treatment for $H$. pylori remains controversial, due to differences in number and type of drugs, dosing, and length of treatment. Quadruple therapy (QT) using omeprazole twice daily with bismuth subcitrate, metronidazole, and tetracycline 4 times daily for 10 days were reported by Korownyk and Kolber [15]. Rizzato et al. [16] analyzed the genetic variability in cagA and someother selected genes of the $\mathrm{H}$. pylori cytotoxinassociated genes pathogenicity island (cagC, cagE, cagL, cagT, cagV and cag Gamma) using DNA extracted from frozen gastric biopsies of $95 \mathrm{cagA}+$ patients with chronic gastritis or gastric cancer in Venezuela and Mexico by sequencing reactions. In this study they reported that polymorphisms in genes coding for energy-supply protein CagE and for the $\beta$ - 1 integrin recognizing CagL may also affect virulence, because they are necessary for a functional secretory system.

\section{References}

1. Realdi G, Dore MP, Fastame L (1999) Extradigestive manifestations of Helicobacter pylori infection. fact and fiction. Dig Dis Sci 44: 229-236.

2. Anastasios R, Goritsas C, Papamihail C, Trigidou R, Garzonis P, et al. (2002) Helicobacter pylori infection in diabetic patients: prevalence and endoscopic findings. Eur J Intern Med 13: 376.

3. Huang SL, Su CH, Chang SC (1997) Tumor necrosis factor-alpha gene polymorphism in chronic bronchitis. Am J Respir Crit Care Med 156: 14361439.

4. Nelson S, Summer WR, Mason CM (2000) The role of the inflammatory response in chronic bronchitis: therapeutic implications. Semin Respir Infect 15: 24-31.

5. Miwa H, Go MF, Sato N (2002) H. pylori and gastric cancer: the Asian enigma Am J Gastroenterol 97: 1106-1112.

6. Marshall BJ, Warren JR (1984) Unidentified curved bacilli in the stomach of patients with gastritis and Peptic ulceration. Lancet 1: 1311-1315.

7. Radosz-KomoniewskaH, Bek T, Jozwiak J, Martirosian G (2005) Pathogenicity of Helicobacter pylori infection. Clin Microbiol Infect 11: 602-610.

8. Lu H, Yamaoka Y, Graham DY (2005) Helicobacter pylori virulence factors: facts and fantasies. Curr Opin Gastroenterol 21: 653-659.

9. Carloni E, Cremonini F, Di Caro S, Padalino S, Gerardino I, et al. (2000) Helicobacter pylori-related extradigestive diseases and effects of eradication therapy. Dig Liver Dis 32: S214-S216.

10. Bamford KB, Andersen L (1997) Host response. Curr Opin Gastroenterol 13 25-30.

11. Vaira D, Malfertheiner P, Mégraud F, Axon AT, Deltenre M, et al. (2000) Noninvasive antigen-based assay for assessing Helicobacter pylori eradication: a European multicenter study. The European Helicobacter pylori HpSA Study Group. Am J Gastroenterol 95: 925-929.

12. (1997) Current European concepts in the management of Helicobacter pylori infection. The Maastricht Consensus Report. European Helicobacter Pylor Study Group. Gut 41: 8-13.

13. Megraud F, Lehours $P$ (2007) Helicobacter pylori detection and antimicrobia susceptibility testing. Clin Microbiol Rev 20: 280-322.

14. Caristo E, Parola A, Rapa A, Vivenza D, Raselli B, et al. (2008) Clarithromycin resistance of Helicobacter pylori strains isolated from children' gastric antrum and fundus as assessed by fluorescent in-situ hybridization and culture on foursector agar plates. Helicobacter 13: 557-563.

15. Korownyk C, Kolber MR (2012) Is quadruple therapy the new triple therapy for H pylori? Can Fam Physician 58: 58.

16. Rizzato C, Torres J, Plummer M, Muñoz N, Franceschi S, et al. (2012) Variations in Helicobacter pylori Cytotoxin-Associated Genes and Their Influence in Progression to Gastric Cancer: Implications for Prevention. PLoS One 7: e29605.

*Corresponding author: Mona Z Zaghloul, Microbiology Unit, Department of Clinical Pathology, Ain Shams University Hospitals, Cairo, Egypt, Tel. 0224023494; E-mail: monazaki_810@hotmail.com

Received February 02, 2012; Accepted February 08, 2012; Published February 10,2012

Citation: Zaghloul MZ (2012) Helicobacter pylori. J Medical Microbiol Diagnosis 1:e104. doi:10.4172/2161-0703.1000e104

Copyright: (c) 2012 Zaghloul MZ. This is an open-access article distributed under the terms of the Creative Commons Attribution License, which permits unrestricted use, distribution, and reproduction in any medium, provided the original author and source are credited. 